\title{
Antihyperlipidemic Effect of Ginsenoside Rg1 in Type 2 Diabetic Mice
}

\author{
Jae Hong Park ${ }^{\dagger}$, Jiyoun Lee ${ }^{\dagger}$, Jiyoung Yeo, Jeong Su Nam and Myeong Ho Jung*
}

School of Korean Medicine, Pusan National University, Yangsan 626-770, Korea

Received April 14, 2011 /Revised May 11, 2011 /Accepted May 13, 2011

\begin{abstract}
Ginsenoside Rg1 is a pharmacologically active component isolated from ginseng. The goal of this study was to clarify the beneficial effects of Rg1 on glucose and lipid metabolism in diabetic animals ( $d b / d b$ mice). To accomplish this, ten week old $d b / d b$ mice were administered $10 \mathrm{mg} / \mathrm{kg}$ of $\operatorname{Rg} 1$ for 15 days. Rg1 did not influence the weight of $d b / d b$ mice when compared with vehicle-treated $d b / d b$ mice. The administration of Rg1 lowered fasting plasma glucose, and improved glucose tolerance. Importantly, Rg1 markedly reduced both plasma triglyceride and free fatty acids, and increased high-density lipoprotein cholesterol (HDL-C) concentrations in $d b / d b$ mice. Rg1 activated promoter activity of chimeric GAL4-PPARa reporter and increased expression of peroxisome proliferator-activated receptor alpha (PPARa) target genes such as carnitine palmitoyltransferase-1 (CPT-1) and acyl-CoA oxidase (ACO), which are involved in fatty acid oxidation. These findings indicated that improvement of lipid profiles by Rg1 may be associated with increased fatty acid oxidation via PPARa activation. Taken together, these results suggest that Rg1 could have beneficial effects for controlling hyperglycemia and hyperlipidemia associated with type 2 diabetes.
\end{abstract}

Key words : Ginsenoside Rg1, type 2 diabetes, hyperlipidemia, $d b / d b$ mice

\section{Introduction}

Ginseng (Panax ginseng C.A. Meyer) is a well-known Chinese medicinal herb that has been widely used for thousands of years throughout Asia owing to its various pharmacological actions $[9,11,21]$. Ginseng is now one of the most popular herbal medicines used nutraceutically, with annual sales of over USD 200 million [29]. Most pharmacological actions of ginseng are attributed to one type of its constituents, namely the ginsenosides. Ginsenosides, the major bioactive components of ginseng, have been shown to account for the pharmacological activities of ginseng, such as anti-inflammatory properties [11], anti-platelet action [27], inhibition of lipoxygenase [5] and 15-hydroxyprostaglandin dehydrogenase [6]. With the development of modern technology, more than 40 different ginsenosides have been isolated and purified from ginseng to date $[13,17,22]$. These compounds can be divided into two classes, protopanaxatriols (Rg1, Rg2, Re, Rf, and Rh1) and protopanaxadials ( $R b 1, R b 2, R c, R d, R g 3, R h 2$, and $R h 3$ ), which have slightly different molecular structures [23]. Among the 40 ginsenosides, Rg1, which is the phytosterol from Panax

\footnotetext{
${ }^{\dagger}$ Equal contributor

*Corresponding author

Tel : +82-51-510-8432, Fax : +82-51-510-8437

E-mail : jung0603@pusan.ac.kr
}

ginseng and the major active molecule from the total saponins of Panax notoginseng (PNS) [19], has received a great deal of attention because it has been shown to possess neurotrophic and neuroprotective effects with cognitive enhancement in many in vitro studies $[20,24]$ as well as anti-aging effects [8]. However, despite these reports, Rg1 has rarely been studied in the field of type 2 diabetes.

Diabetes mellitus is a group of metabolic diseases, and two types (type $1 \& 2$ ) of diabetes have a distinct pathogenesis; however, hyperglycemia and diverse life-threatening complications including atherosclerosis resulting from long-term hyperglycemia are their most common features. More than $90 \%$ of diabetic patients have type 2 diabetes and suffer from severe insulin resistance [15]. Major complications of type 2 diabetes, such as cardiovascular disease, are partly due to associated abnormalities of plasma lipid and lipoprotein metabolism. Apart from glycemic control, the regulation of lipid metabolism may be an important therapeutic target against the complications associated with type 2 diabetes [18].

Accordingly, this study was designed to clarify the possibility of Rg1 as an effective candidate to ameliorate hyperglycemia and hyperlipidemia in a diabetic animal model ( $d b / d b$ mice). 


\section{Materials and Methods}

\section{Animals and diets}

Twenty one male C57Bl/KsJ- $d b / d b$ mice (8 weeks old) were obtained from Jackson Laboratory (Bar Harbor, ME, USA). The mice were all individually housed in polycarbonate cages under a 12-h light-dark cycle at, $21-23^{\circ} \mathrm{C}$ and $40-60 \%$ humidity. After a 2-week adaptation period, the 10-week-old mice were randomly divided into three groups $(\mathrm{n}=7)$, a diabetic control, acarbose, and Rg1. All groups were fed a standard AIN-76 semi-synthetic diet [2,3]. The mice had free access to food and water, and their body weight was measured once every five days throughout the experiment. The diabetic control group was orally administered deionized water and two experimental groups (acarbose, and $\operatorname{Rg} 1$ ) were orally administered acarbose (50 $\mathrm{mg} / \mathrm{kg} \mathrm{BW})$ or Rg1 (10 mg/kg BW) for 15 days. The mice were then starved for $12 \mathrm{hrs}$, after which they were anesthetized with ether and their blood samples were taken from the inferior vena cava to measure the plasma biomarkers $\left(\mathrm{HbA}_{1 \mathrm{c}}\right.$, insulin, glucagon, etc.). The mice were handled in strict accordance with the Pusan National University guidelines for the care and use of laboratory animals.

Plasma glucose, insulin, glucagon levels and lipids contents

The blood glycated hemoglobin $\left(\mathrm{HbA}_{1 c}\right)$ of each sample sacrificed mice was measured using a MicroMatTM II Hemoglobin $\mathrm{A}_{1 \mathrm{c}}$ Test (Bio-Rad Laboratories, Hercules, CA, USA). The plasma insulin and glucagon (Mouse ELISA Kit, ALPCO Diagnostics, Salem, NH, USA) levels were determined using a quantitative sandwich enzyme immunoassay kit. In addition, the plasma concentrations of glucose, total cholesterol, triglyceride, and HDL-cholesterol (Asan Diagnostics, Seoul, Korea) were determined using an enzymatic method. The plasma free fatty acids (FFAs) concentrations were determined using an enzymatic colorimetric method (Wako Pure Chemical Industries, Japan). All blood samples obtained were centrifuged at $1,000 \times g$ for $15 \mathrm{~min}$ at $4^{\circ} \mathrm{C}$ for biochemical analysis.

\section{Intraperitoneal glucose tolerance test (IPGTT)}

One day before the sacrifice, an intraperitoneal glucose tolerance test (IPGTT) was conducted on all of the $d b / d b$ mice after a 12-h overnight fast. To determine the glucose toler- ance, the mice were intraperitoneally injected with glucose $(0.5 \mathrm{~g} / \mathrm{kg} \mathrm{BW})$ and the glucose concentrations of blood drawn from the tail vein were determined immediately upon collection at 30,60, and 120 min after glucose injection using a Glucometer (GlucoDr, Allmedicus, Anyang, Korea).

\section{GAL4/PPARa chimera assay}

The PPARa ligand-binding activity was measured using a GAL4/PPARa chimera. COS-7 monkey kidney cells were transfected with pFA-hPPARa, pFR-Gal4 (UAS-Gal4-luciferase) and pFR-galactosidase (Stratagene, La Jolla, CA, USA) using Genejuice (Novagen, Madison, WI, USA). After transfection for $24 \mathrm{hr}$, the cells were incubated with Rg1 or WY14643 (Sigma, St. Louis, MO, USA) at $5 \mu \mathrm{M}$ or $2 \mu \mathrm{M}$ for $24 \mathrm{hr}$. The luciferase activities were then determined with a luciferase assay system kit (Promega, Madison, WI, USA).

\section{Real-time RT-PCR}

For the quantification of mRNA expression of CPT-1 and ACO, total RNA was extracted using TRIzol reagent (Invitrogen, Carlsbad, CA, USA) and subjected to reverse transcription using reverse transcriptase (Promega). The resulted cDNA was then subsequently amplified with gene-specific primers by PCR using a fluorescence temperature cycler (Chromo4, Real-Time PCR System; Bio-Rad, Hercules, CA, USA).

\section{Statistical analysis}

All data are presented as the means \pm SE. The data were evaluated by one-way ANOVA and the differences between means were determined using Tukey's multiple-range test. All analyses were conducted using GraphPad prism ver. 5.01. Significant difference between two groups was determined using Student's t-test. Values were considered statistically significant at $p<0.05$.

\section{Results}

\section{Effect of Rg1 on body weight}

The body weight of $d b / d b$ mice in the vehicle-treated group and Rg1-treated group showed a slight decrease from Day 0 to Day 15. However, there was no significant difference in body weight between the vehicle group and the Rg1-treated group (Fig. 1), suggesting that Rg1 does not affect the bodyweight of $d b / d b$ mice. 


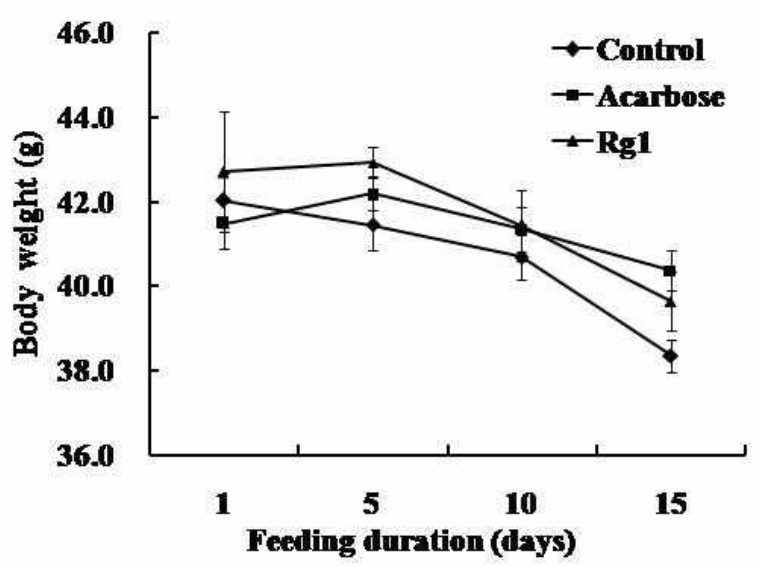

Fig. 1. Changes in the body weight of Rg1-treated C57BL/ $\mathrm{KsJ}-d b / d b$ mice.

Effect of $\mathrm{Rg} 1$ on plasma glucose, glycated hemoglobin, insulin and glucagon

We investigated the effect of Rg1 on biochemical parameters in the blood of $d b / d b$ mice after fasting for $12 \mathrm{hr}$. As shown in Fig. 2, the plasma glucose level of Rg1-treated $d b / d b$ mice was reduced when compared with vehicle-treated $d b / d b$ mice (Fig. 2A). The glycated hemoglobin levels were also slightly lower in the Rg1-treated mice, but this difference was not significant (Fig. 2B). The plasma insulin level of the Rg1-treated mice was significantly higher than that of ve- hicle-treated $d b / d b$ mice, whereas the plasma glucagon levels were markedly lower (Fig. 2C and 2D).

\section{Effect of Rg1 on IPGTT}

We conducted an IPGTT assay to determine the effects of $\operatorname{Rg} 1$ on glucose homeostasis in $d b / d b$ mice, and the results were presented as a percentage of the value at the time of the glucose injection (Fig. 3). The blood glucose was increased for up to $30 \mathrm{~min}$ after glucose injection in vehicle or treated $d b / d b$ mice. However, the blood glucose level began to decrease in the Rg1 and acarbose-treated mice at 60 min after glucose injection when compared to the vehicle control $d b / d b$ mice. The blood glucose level failed to return to the baseline after $120 \mathrm{~min}$ in all $d b / d b$ mice, but the glucose level in the Rg1-treated mice was much lower than that in the vehicle-treated $d b / d b$ mice, suggesting that Rg1 significantly improves glucose homeostasis in $d b / d b$ mice.

\section{Effect of Rg1 on plasma lipid contents}

We examined the effects of $\operatorname{Rg} 1$ on plasma lipid contents in $d b / d b$ mice. The plasma cholesterol level was not significantly influenced by $\operatorname{Rg} 1$ or acarbose treatment (Fig. 4A). However, Rg1 significantly reduced both the plasma triglyceride and free fatty acid concentrations when compared with those of vehicle or acarbose-treated mice (Fig. 4B \&
(A)

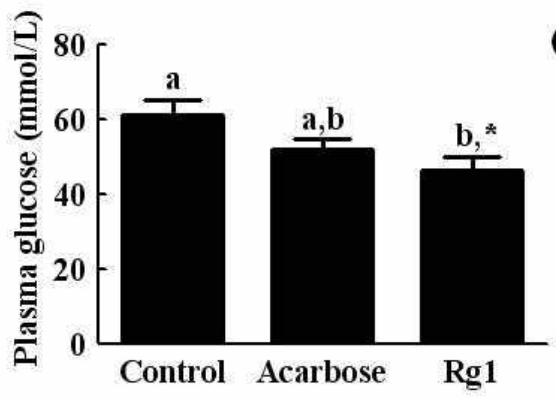

(C)

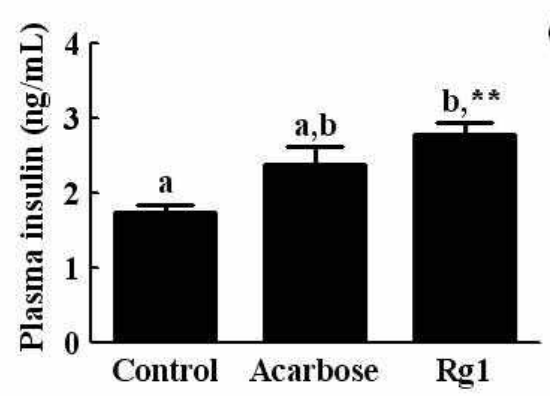

(B)

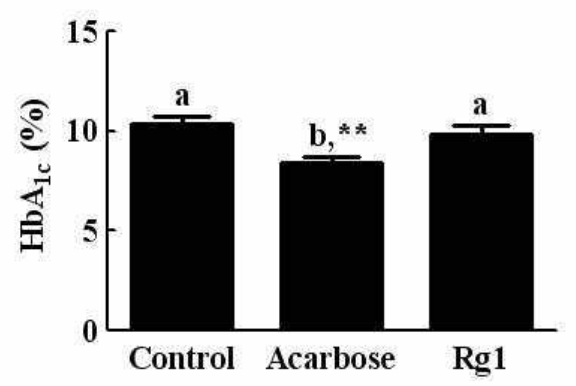

(D)

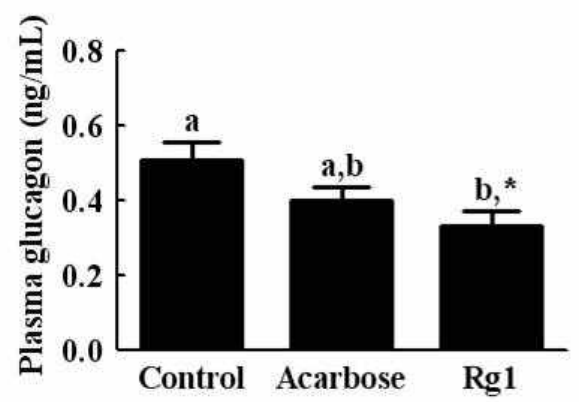

Fig. 2. Effects of Rg1 on plasma glucose (A), the glycated hemogluobin $\left(\mathrm{HbA}_{1 c}\right)(\mathrm{B})$, insulin (C), and glucagon (D) in $d b / d b$ mice over 15 days. Values are expressed as the means $\pm \mathrm{SE}, \mathrm{n}=7 .{ }^{\mathrm{ab}}$ means not sharing a common letter are significantly different $(p<0.05)$. 


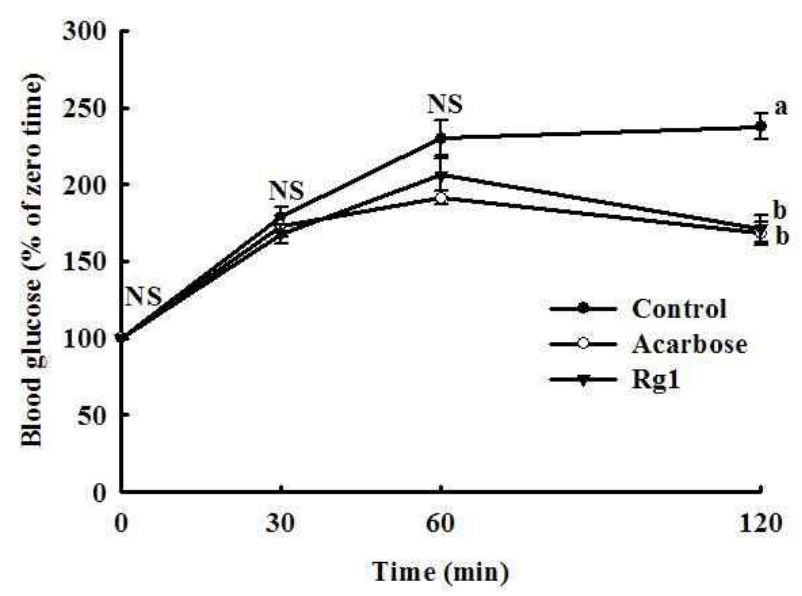

Fig. 3. Effects of Rg1 on the intraperitoneal glucose tolerance test (IPGTT) in C57BL/KsJ- $d b / d b$ mice. The blood glucose concentration was measured at the indicated times and presented as a percentage of the level at the time of glucose injection. Values are the means $\pm S E, n=7$. ${ }^{a b}$ means not sharing a common letter are significantly different $(p<0.05)$. NS: no significant

$4 \mathrm{C}$ ). Furthermore, Rg1 increased the HDL-cholesterol (Fig. 4D), suggesting that Rg1 can ameliorate lipid metabolism. To clarify the mechanism underlying the effect of Rg1 on lipid improvement, we investigated whether Rg1 activates PPARa using cell-based GAL4/PPARa chimera trans- activation assays. As shown in Fig. 5A, Rg1 increased the PPARa-dependent luciferase activity similar to WY14643, an agonist of PPARa, and stimulated PPARa target genes including CPT-1, ACO in SK-Hep1 cells (Fig. 5B). Taken together, these findings suggest that Rg1 activates fatty acid oxidation and then improves hyperlipidemia.

\section{Discussion}

The role of Rg1 in the severe hyperglycemic state has not yet been fully established; therefore, the effect of Rg1 on hyperglycemia and hyperlipidemia in the $d b / d b$ mice was investigated by comparison with acarbose, which is widely used as a prescription drug for the treatment of type 2 diabetes.

In general, hyperglycemia is a modifiable risk factor that can have a deleterious effect on the development and progression of microvascular and macrovascular complications in patients with type 2 diabetes [12]. Hence, many studies suggest that diabetic treatment may be required to reach hyperglycemic control targets in patients who have early-stage type 2 diabetes [25]. When we measured fasting blood glucose of mice before sacrifice, the fasting blood glucose level was lower in Rg1-treated mice. Furthermore, Rg1 improved glucose tolerance, suggesting that Rg1 improves glucose
(A)

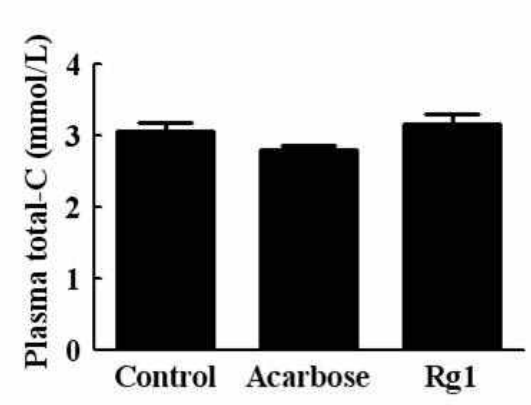

(C)

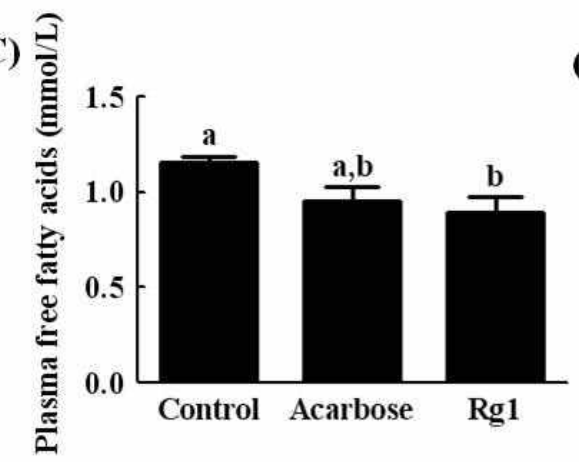

(B)

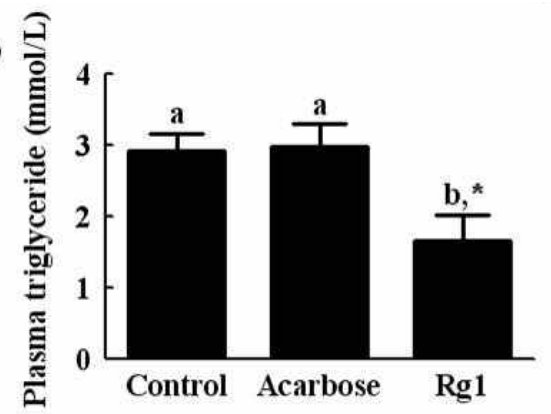

(D)

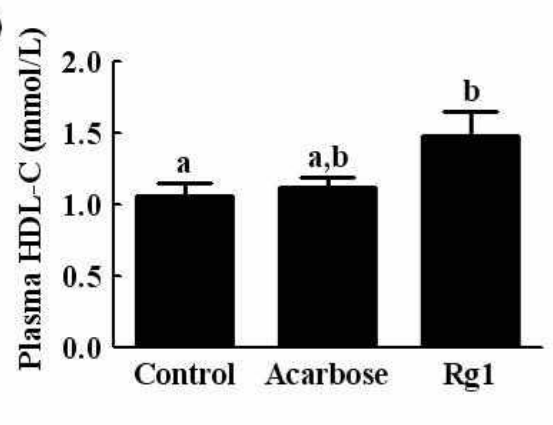

Fig. 4. The effects of Rg1 on plasma total cholesterol (A), triglyceride (B), free fatty acids (C), and HDL-cholesterol (D) in $d b / d t$ mice over 15 days. Values are expressed as the means $\pm \mathrm{SE}, \mathrm{n}=7$. ${ }^{\mathrm{ab}}$ means not sharing a common letter are significantly different $(p<0.05)$. 
(A)

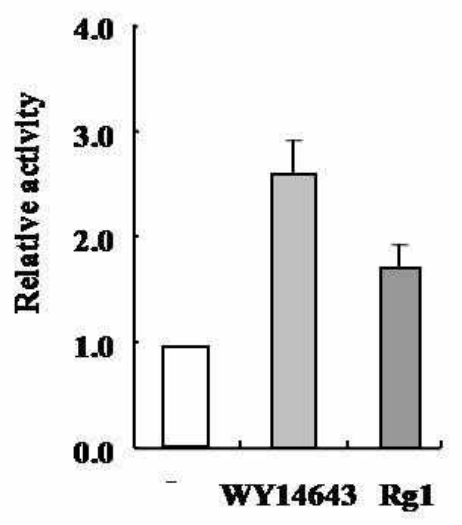

(B)

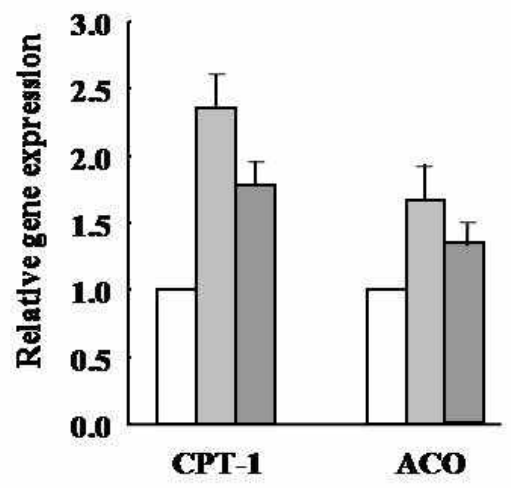

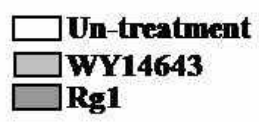

Fig. 5. The effect of Rg1 on PPARa activation. (A) The PPARa ligand-binding activity was measured using a GAL4/PPARa chimera assay in Rg1-treated cells. (B) Real time PCR was conducted to determine the mRNA expression of CPT-1 and ACO in Rg1-treated Sk-Hep1.

homeostasis. The recent study showed that Rg1 suppressed hepatic glucose production via liver kinase B1 (LKB1)-AMPactivated protein kinase (AMPK)-forkhead box class $\mathrm{O} 1$ (FoxO1) pathway [16]. We also found that Rg1 activated AMPK in SK-Hep1 cells (data not shown). Therefore, the suppression of hepatic glucose production by stimulation of AMPK may be responsible for antihyperglycemic effect of Rg1. Additionally, the plasma insulin levels were significantly higher in the Rg1-treated and acarbose mice than in diabetic control mice, whereas the glucagon levels were reduced by $\operatorname{Rg} 1$ treatment. These results appeared to indicate that Rg1 positively affects regulation of hyperglycemia by removing glucose from the blood via increased insulin secretion and decreased glucagon secretion.

The lipotoxic theory states that the accumulation of lipids in target organs such as skeletal muscle, kidneys, the pancreas and the heart may contribute to the development of obesity-related disorders [10]. Changes in the plasma lipid concentration are a frequent complication in patients with diabetes mellitus $[14,28]$, which certainly contributes to the development of vascular disease. Diabetic dyslipidemia is characterized by high triglyceride (TG) levels, low HDL-C and increased low density lipoprotein cholesterol (LDL) $[1,4]$. This atherogenic lipid profile contributes to an excess risk of cardiovascular disease (CVD) in individuals with type 2 diabetes. The dyslipidemia is partially corrected by control of the hyperglycemia, but abnormalities persist, in part due to the effects of insulin resistance on lipoprotein metabolism $[7,26]$. Low levels of HDL-C and apo A-I are also characteristic of type 2 diabetes. Accordingly, the effects of $\operatorname{Rg} 1$ on the plasma lipid concentrations were also investigated. While the plasma lipid concentrations, total cholesterol, and triglyceride were significantly increased in the diabetic control mice, the Rg1- treated mice showed low levels of these compounds, suggesting that Rg1 improved hyperlipidemia. We also found that Rg1 activates PPARa and increases CPT-1 and ACO expression in SK-Hep1 cells. Thus, these effects may lead to reduced synthesis and secretion of triglycerides, thereby decreasing the liberation of fatty acids, resulting in antihyperlipidemia.

In conclusion, Rg1 lowered plasma glucose, which appeared to be partly mediated via AMPK activation and an increase in plasma insulin, and improved plasma lipids such as free fatty acid and triglycride in the $d b / d b$ mice via PPARa activation. Therefore, these results suggest that the antihyperglycemic and antihyperlipidemic properties of Rg1 could be beneficial for the prevention of diabetic complications such as cardiovascular diseases and mild management of type 2 diabetes.

\section{Acknowledgement}

This work was supported by a 2-Year Research Grant of Pusan National University. 


\section{References}

1. Aasum, E., A. D. Hafstad, D. L. Severson, and T. S. Larsen. 2003. Age-dependent changes in metabolism, contractile function, and ischemic sensitivity in hearts from $\mathrm{db} / \mathrm{db}$ mice. Diabetes 52, 434-441.

2. American Institute of Nutrition. 1980. Report of Ad Hoc committee on standards for nutritional studies. J. Nutr. 110, $1717-1726$

3. American Institute of Nutrition. 1977. Report of the American institute of nutrition ad hoc committee on standards for nutritional studies. J. Nutr. 107, 1340-1348.

4. Andallu, B., A. V. Vinay Kumar, and NCh. Varadacharyulu. 2009. Lipid abnormalities in streptozotocin-diabetes: Amelioration by Morus indica L. cv Suguna leaves. Int. J. Diabetes Dev. Ctries. 29, 123-128.

5. Anhäuser, M. 2003. Pharmacists seek the solution of a shaman. Drug Discov. Today 8, 868-869.

6. Atta, Ur R. and K. Zaman. 1989. Medicinal plants with hypoglycemic activity. J. Ethnopharmacol. 26, 1-55.

7. Chen, X., X. Bai, Y. Liu, L. Tian, J. Zhou, Q. Zhou, J. Fang, and J. Chenl. 2009. Anti-diabetic effects of water extract and crude polysaccharides from tuberous root of Liriope spicata var. prolifera in mice. J. Ethnopharmacol. 122, 205-209.

8. Cheng, Y., L. H. Shen, and J. T. Zhang. 2005. Anti-amnestic and anti-aging effects of ginsenoside Rg1 and Rb1 and its mechanism of action. Acta. Pharmacol. Sin. 26, 143-149.

9. DeFronzo, R. A. 1999. Pharmacologic therapy for type 2 diabetes mellitus. Ann. Intern. Med 131, 281-303.

10. De Sotillo, D. V. R. and M. Hadley. 2002. Chlorogenic acid modifies plasma and liver concentrations of: cholesterol, triacylglycerol, and minerals in (fa/fa) Zucker rats. J. Nutr. Biochem 13, 717-726.

11. Gaster, B. and I. B. Hirsch. 1998. The effects of improved glycemic control on complications in type 2 diabetes. Arch Intern. Med 158, 134-140.

12. Hanefeld, M. and T. Temelkova-Kurktschiev. 2002. Control of post-prandial hyperglycemia- an essential part of good diabetes treatment and prevention of cardiovascular complications. Nutr. Metab. Cardiovasc. Dis. 12, 98-107.

13. Hou, J. P. 1977. The chemical constituents of ginseng plants. Comp. Med East West 5, 123-145.

14. Jang, Y. J., J. K. Kim, M. S. Lee, I. H. Ham, W. K. Whang, K. H. Kim, and H. J. Kim. 2001. Hypoglycemic and hypolipidemic effects of crude saponin fractions from Panax ginseng and gynostemma pentaphyllum. Yakhak Hoechi 45, 545-556.

15. Kim, M. J., K. H. Leem, and H. K. Kim. 2009. Hydrangea dulcis folium preserves b-cell mass in diabetic $\mathrm{db} / \mathrm{db}$ mice. Food Chem Toxicol. 47, 1685-1688.

16. Kim, S. J., H. D. Yuan, and S. H. Chung. 2010. Ginsenoside Rg1 suppresses hepatic glucose production via AMP-activated protein kinase in HepG2 cells. Biol. Pharm Bull. 33, 325-328.
17. Lee, S. M., H. J. Shon, C. S. Choi, T. M. Hung, B. S. Min, and K. Bae. 2009. Ginsenosides from heat processed ginseng. Chem Pharm Bull. (Tokyo) 57, 92-94.

18. Liu, G., B. Wang, J. Zhang, H. Jiang, and F. Liu. 2009. Total panax notoginsenosides prevent atherosclerosis in apolipoprotein E-knockout mice: Role of downregulation of CD40 and MMP-9 expression. J. Ethnopharmacol. 126, 350-354.

19. Ng, T. B. 2006. Pharmacological activity of sanchi ginseng (Panax notoginseng). J. Pharm Pharmacol. 58, 1007-1019.

20. Nishijo, H., T. Uwano, Y. M. Zhong, and T. Ono. 2004. Proof of the mysterious efficacy of ginseng: basic and clinical trials: effects of red ginseng on learning and memory deficits in an animal model of amnesia. J. Pharmacol. Sci. 95, 145-152.

21. Rosenbloom, A. L., J. R. Joe, R. S. Young, and W. E. Winter. 1999. Emerging epidemic of type 2 diabetes in youth. Diabetes Care 22, 345-354.

22. Sugimoto, S., S. Nakamura, H. Matsuda, N. Kitagawa, and M. Yoshikawa. 2009. Chemical constituents from seeds of Panax ginseng: structure of new dammarane-type triterpene ketone, panaxadione, and HPLC comparisons of seeds and flesh. Chem Pharm Bull. 57, 283-287.

23. Tawab, M. A., U. Bahr, M. Karas, M. Wurglics, and M. Schubert-Zsilavecz. 2003. Degradation of ginsenosides in humans after oral administration. Drug Metab. Dispos. 31, 1065-1071.

24. Tohda, C., N. Matsumoto, K. Zou, M. R. Meselhy, and K. Komatsu. 2004. Abeta (25-35)-induced memory impairment, axonal atrophy, and synaptic loss are ameliorated by M1, A metabolite of protopanaxadiol-type saponins. Neuropsychopharmacology 29, 860-868.

25. Van Gaal, L. F. and I. H. De Leeuw. 2003. Rationale and options for combination therapy in the treatment of type 2 diabetes. Diabetologia 46, 44-50.

26. Verreth, W., J. Ganame, A. Mertens, H. Bernar, M. C. Herregods, and P. Holvoet. 2006. Peroxisome proliferator-activated receptor-alpha,gamma-agonist improves insulin sensitivity and prevents loss of left ventricular function in obese dyslipidemic mice. Arterioscler. Thromb. Vasc. Biol. 26, 922-928.

27. Xie, J. T., H. H. Aung, J. A. Wu, A. S. Attele, and C. S. Yuan. 2002. Effects of American ginseng berry extract on blood glucose levels in $o b / o b$ mice. Am J. Chin. Med 30, 187-194.

28. Xie, J. T., Y. P. Zhou, L. Dey, A. S. Attele, J. A. Wu, M. $\mathrm{Gu}, \mathrm{K}$. S. Polonsky, and C. S. Yuan. 2002. Ginseng berry reduces blood glucose and body weight in $\mathrm{db} / \mathrm{db}$ mice. Phytomedicine 9, 254-258.

29. Yue, P. Y., N. K. Mak, Y. K. Cheng, K. W. Leung, T. B. Ng, D. T. Fan, H. W. Yeung, and R. N. Wong. 2007. Pharmacogenomics and the Yin/Yang actions of ginseng: anti-tumor, angiomodulating and steroid-like activities of ginsenosides. Chin Med 2, 6. 
초록 : 제2형 당뇨병 모델 마우스에서 ginsenoside Rg1의 항당뇨 효과

박재홍 · 이지연 · 여지영 · 남정수 · 정명호*

(부산대학교 한의학전문대학원 양생기능의학부)

Ginsenoside Rg1은 인삼에서 분리한 약물학적인 활성을 가지는 물질이다. 본 연구는 $\operatorname{Rg} 1$ 이 제2형 당뇨병 모델 동물에서 혈당과 지질대사에 유익한 효과를 가지는지를 확인하기 위한 목적으로 수행되었다. 10 주령의 $\mathrm{db} / \mathrm{db}$ 마우스에 $\operatorname{Rg} 1$ 을 $10 \mathrm{mg} / \mathrm{kg}$ 농도로 15 일간 경구투여한 결과 공복혈당이 감소하였고, 포도당 내성이 개선되었다. 특히 혈중 중성지방과 유리지방산이 유의적으로 감소하였고 혈중 HDL-콜레스테롤이 증가되었다. 또한 chimeric GAL4-PPARa receptor 활성 프로모터를 활성화시켰고 PPARa gene인 CPT-1 (carnitine palmitoyltransferase-1) 과 ACO (acyl-CoA oxidase)의 발현을 증가시켰는데 이것으로 Rg1의 지질대사 개선이 PPARa 활성에 의한 지방 산 산화에 의한 것임을 확인할 수 있었다. 모든 결과를 종합해 볼 때, Rg1은 제 2 형 당뇨병과 관련된 고혈당증과 고지혈증에 유용한 효과를 가짐을 확인하였다. 